\title{
The role of small-scale spatial location on macroinvertebrate community in an intermittent stream
}

\author{
Gemma Burgazzi ${ }^{1, *}$, Simone Guareschi ${ }^{2}$ and Alex Laini ${ }^{1}$ \\ ${ }^{1}$ Department of Chemistry, Life Sciences and Environmental Sustainability, University of Parma, Parco Area \\ delle Scienze 11/A - 43124 Parma, Italy. \\ 2 Department of Ecology and Hydrology, Regional Campus of International Excellence "Campus Mare \\ Nostrum" University of Murcia, Spain. \\ * Corresponding author: gemma.burgazzi@unipr.it
}

Received: 20/12/17 Accepted: 08/05/18

\begin{abstract}
The role of small-scale spatial location on macroinvertebrate community in an intermittent stream

Macroinvertebrate communities exhibit wide variability in diversity, abundance and structure on different spatial scales. Space is currently used as an explicit predictor to discriminate between environmental forcing and biotic processes on large- and medium-sized scales, but is generally neglected on smaller scales. To bridge this gap, we considered environmental (depth) and spatial variables (spatial location and structure) to explain the diversity, abundance and community patterns of macroinvertebrate communities on the reach scale by geostatistical and multivariate spatial analyses. Sampling was performed in spring 2015 using a grid sampling design along an intermittent watercourse reach (the Baganza stream, Northern Italy). Overall 5493 organisms belonging to 25 taxa were collected and identified, with Chironomidae, Baetidae and Naididae being the most abundant taxa. The spatial variables explained a consistent fraction of abundance and taxa richness variability both individually and jointly with depth. The latter was a good predictor of abundance, but not of taxa richness. Our results suggest that while organisms seem able to occupy almost any position in the watercourse, their abundance is modulated by habitat preference. This study represents a starting point to understand how habitat filtering and biotic processes act on macroinvertebrates communities on a very small scale. Our findings improve knowledge about the small scale organisation of macroinvertebrate communities in intermittent streams. Biomonitoring, restoration ecology and habitat suitability modelling could benefit from our approach.
\end{abstract}

Key words: small scale, macroinvertebrate community, spatial structure, variance partitioning, spatial coordinates

\section{RESUMEN}

El papel de la localización espacial a pequeña escala en la comunidad de macroinvertebrados en un río intermitente

Las comunidades de macroinvertebrados presentan elevada variabilidad en términos de diversidad, abundancia y estructura a diferentes escalas espaciales. La componente espacial es empleada generalmente a gran y mediana escalas (cuenca, rio), como predictor para discriminar entre procesos ambientales y biológicos, pero generalmente no se tiene en cuenta a una escala más pequeña (local, tramo fluvial). En este estudio, se han considerado variables ambientales (profundidad) y espaciales (posición y estructura espacial) con el objetivo de explicar los patrones de diversidad, abundancia y estructura de la comunidad de macroinvertebrados a escala de tramo. Esto ha sido posible gracias a herramientas de análisis geoestadisticas y espaciales multivariantes. El muestreo se realizó en la primavera de 2015 utilizando un diseño en cuadrícula aplicado a lo largo de un tramo de un río intermitente (río Baganza, Norte de Italia). En total fueron identificados 5493 individuos pertenecientes a 25 taxones, siendo los representantes de las familias Chironomidae, Baetidae y Naididae los más abundantes. Las variables espaciales explicaron una importante fracción de la abundancia y riqueza de taxones tanto de forma individual como conjuntamente con la profundidad. Este último factor fue un buen predictor de la abundancia, pero no estuvo relacionado con la riqueza de taxones. Los resultados sugieren que mientras los organismos parecen capaces de ocupar básicamente cualquier 
posición en el cauce fluvial, su abundancia se ve afectada por las preferencias de hábitats. Este estudio piloto representa un punto de partida para entender mejor como los procesos bióticos y de preferencia de hábitat afectan la comunidad de macroinvertebrados a pequeña escala. Los resultados ayudan a mejorar los conocimientos sobre la organización de las comunidades de macroinvertebrados en ríos intermitentes a escala de tramo. Diferentes disciplinas de la ecología acuática (biomonitoreo, restauración fluvial, modelos de disponibilidad de hábitats) pueden obtener una valiosa información de nuestro estudio y tipo de enfoque.

Palabras clave: distribución local, macroinvertebrados, estructura espacial, partición varianza, coordenadas espaciales

\section{INTRODUCTION}

Macroinvertebrate communities exhibit high levels of variability in diversity, abundance and structure on different spatial scales (e.g., Parson et al., 2003; Mykrä et al., 2007). Numerous works have been carried out on the regional or catchment scale, where habitat filtering, biotic interactions and dispersal-driven dynamics concepts explain this variability (e.g., Siqueira $e t$ al., 2012; Astorga et al., 2014; Gutiérrez-Cánovas et al., 2015). However, knowledge about the role played by these processes in structuring aquatic macroinvertebrate community on local or reach scales is still limited and often contradictory.

Studies focused on different spatial scales report wide unexplained variation on the small scale (e.g., Boyero \& Bailey, 2001; Boyero, 2003; Heino et al., 2004; Lamouroux et al., 2004; Bruno et al., 2014). Several environmental parameters have been reported as key factors related to macroinvertebrate community features (e.g., Downes et al., 2000, Brooks et al., 2005; Bo et al., 2007; Barnes et al., 2013; Laini et al., 2018). Among them, depth has been stressed as being crucial for shaping macroinvertebrate communities (e.g., Bournaud et al., 1998; Gayraud \& Philippe, 2001; Fenoglio et al., 2004), and lotic ecosystem properties, like leaf-litter decomposition (Martinez et al., 2016). Space has traditionally received very little attention, but can play a determinant role in explaining the structuring of biological communities, and should be recognised as a covariate and be explicitly introduced into statistical models (Stoch et al., 2016; Tolonen et al., 2017). Surprisingly, the spatial location of samples is explicitly considered on the large scale (e.g. Grönross et al., 2013), but is generally neglected on the small scale.
Spatial location enables the study of spatial autocorrelation, namely the tendency of closer objects being more similar than things further apart in space (Bonada et al., 2012). Taking into account spatial autocorrelation could help to discriminate among the factors that affect the macroinvertebrate community structure and to identify specific patterns. Indeed spatial autocorrelation has been used to unravel the internal dynamics to the community itself (e.g. dispersal ability, biotic interactions), which largely depend on distance, or on missing environmental covariates (Diggins \& Newman, 2009).

Furthermore, the combined focus of small scale and intermittent streams on macroinvertebrate communities has not been widely considered to date, despite temporary river ecology representing a main worldwide challenge in aquatic science (Datry et al., 2014; Datry et al., 2017), and intermittent systems being the most common aquatic systems in South Europe (Tockner et al., 2009).

To bridge this gap, our research focuses on an intermittent stream to investigate the contribution of depth and spatial location on structuring a macroinvertebrate community. More specifically, we aim to answer the following questions: 1) do spatial location and depth explain community composition on the reach scale? 2) do taxonomic richness and organism abundance follow the same trend? We hypothesise that on the small scale (reach level), macroinvertebrates present a strong spatially structured community that is driven by watercourse features. Our research is one of the first to also consider spatial variables explicitly, and not only environmental variables, on the reach scale and may therefore, improve knowledge about the small scale organisation of macroinvertebrate communities in intermittent streams. 


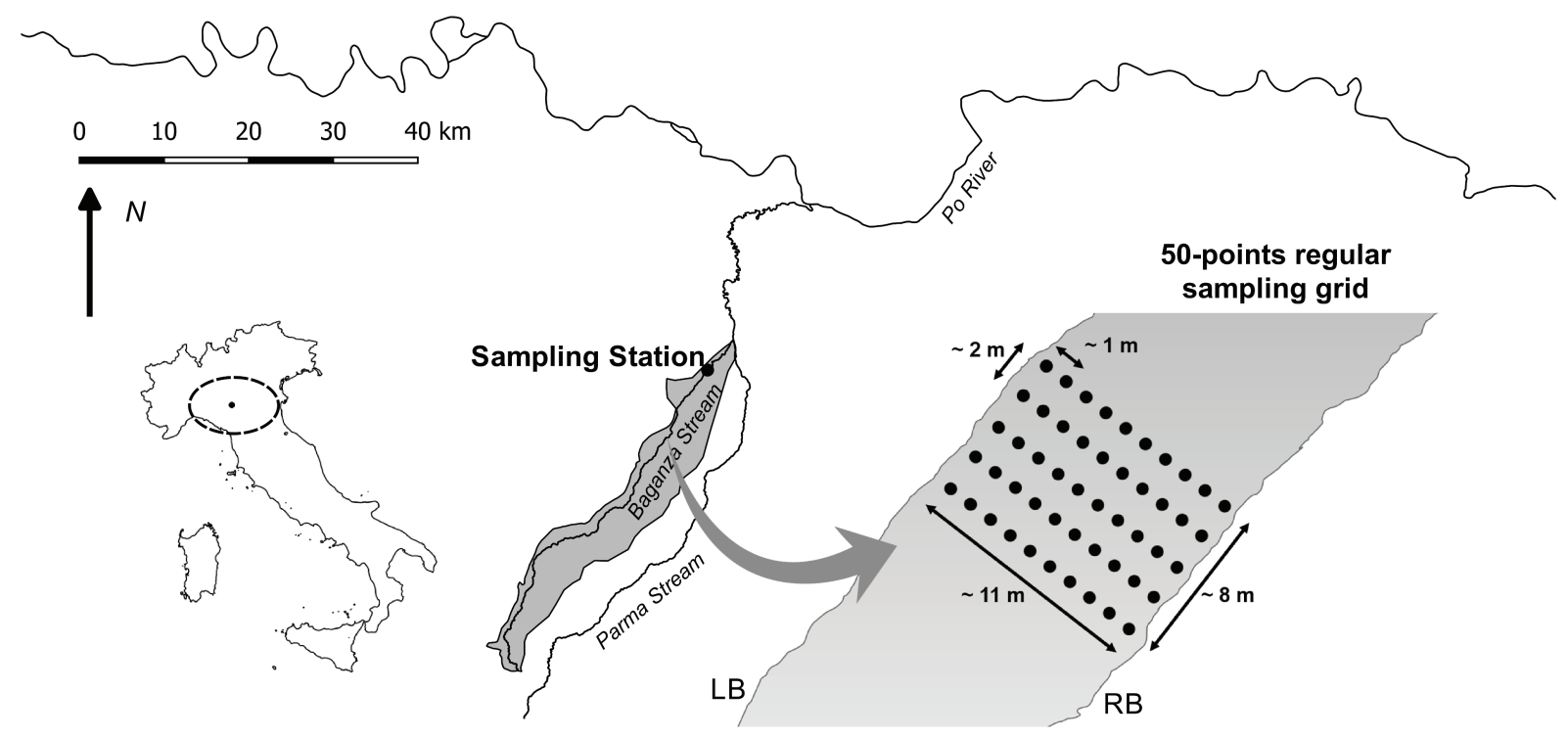

Figure 1. Study area and the sampling grid at the Baganza stream, with indications of grid dimensions. Black dots represent the 50 Surber points. $\mathrm{RB}=\mathrm{Right}$ riverbank; LB=Left riverbank. Área de estudio y diseño de muestreo en cuadrícula en el lecho del río Baganza con indicación de las dimensiones. Los puntos representan las 50 unidades obtenidas con el Surber. RB=Orilla derecha; LB=Orilla izquierda.

\section{MATERIAL AND METHODS}

\section{Study area}

Sampling was carried out in the Baganza Stream (Emilia-Romagna, Northern Italy), an intermittent $58 \mathrm{~km}$-long watercourse located in the Po basin, with a basin surface of $225 \mathrm{~km}^{2}$ and a mean annual discharge of $5.2 \mathrm{~m}^{3} / \mathrm{s}$. Intermittent streams are widespread in the study area (Skoulikidis et al., 2017), where they present an extended dry phase (minimum 3 months) throughout summer and most of autumn, with relevant discharges usually from winter to spring (following rain distribution). The sampling site (San Martino Sinzano, $44^{\circ} 44^{\prime}$ $48.57^{\prime \prime} \mathrm{N}, 10^{\circ} 15^{\prime} 55.34^{\prime \prime} \mathrm{E}, 115 \mathrm{~m}$ a.s.1.) forms part of a near-natural lowland stretch with a mixture of riffles and runs, no deep pools and a limited slope. Here active channel width is approximately 135 $\mathrm{m}$, but only a limited portion is occupied by a main 5-10 metre-wide channel (Fig. 1). Agricultural land use and small-scattered urban areas cover adjacent zones, while dense riparian vegetation runs alongside the entire stretch.

\section{Experimental design}

In order to fulfil the aims, a grid sampling design was created by placing marked stones on the riverbed at regular intervals along five transects (details in figure 1) for 50 points. Depth, substrate grain size and spatial location were recorded for each point. Grain size was classified according to the Italian Biomonitoring System (Buffagni \& Erba, 2007). Substrate was dominated by microlithal $(82$ $\%$; diameter 2-6 cm) with minor percentages of gravel $(10 \% ; 0.2-2 \mathrm{~cm})$ and mesolithal $(8 \%$; 6-20 $\mathrm{cm})$. However, due to the homogeneity of the substrate in the sampling grid and the preliminary analysis (not displayed), substrate grain size was omitted from the statistical analysis.

Macroinvertebrates were collected immediately upstream from each of the 50 marked stones using a Surber net ( $500 \mu \mathrm{m}$ mesh size) and a 0.05 $\mathrm{m}^{2}$ frame area. Samples were kept separately in 1-litre PET bottles and were then fixed with $90^{\circ}$ ethanol for laboratory sorting purposes. Identification was made at the family or genus level (Ephemeroptera and Plecoptera) according to the 
taxonomic guide proposed by Tachet et al. (2010). To avoid any bias due to temporal heterogeneity, sampling was carried out intensively during flow conditions in spring (May 2015) before the drought period (summer). The spring samplings enabled us to obtain data in the wet phase. At the same time, this season may represent a period with high invertebrate activities in these intermittent systems before the adult emergence period. A similar temporal approach has been considered in numerous Mediterranean systems in South Europe (e.g., Bruno et al., 2014).

\section{Data analysis}

Three community variables were considered herein: community composition, taxa richness and abundance.

Firstly, community composition was explored by non-Metric Multidimensional Scaling (nMDS), a spatial ordination technique that represents a set of objects along a predetermined number of axes by maintaining the ordering relationships among them (Borcard et al., 2011). Modified Gower distance was used as the dissimilarity measure (following Anderson et al., 2006) and goodness of ordination was assessed with the stress measure. Depth, the $\mathrm{x}$-axis and the $\mathrm{y}$-axis were fitted onto nMDS ordination by the envfit function of the vegan package (R Core Team, 2016).

The next step was to model the spatial organisation of macroinvertebrate community according to two statistical approaches. In this work spatial location was implemented as both coordinates and spatial structure to obtain a more exhaustive view (see the details below).

The first approach used herein involved applying variance partitioning to assess the relationship among the response variables (community composition, taxa richness and abundance) with the explanatory variables (coordinates, spatial structure and depth). This method enabled us to assess the contribution of the explanatory variables by the decomposition of R-squared, as described in Peres-Neto et al. (2006). Briefly, total variance is partitioned between the explained and unexplained (or residual) variance, with the explained variance split into single and joint contribution.
Explained and unexplained variance should sum $100 \%$. The spatial structure was modelled by the principal coordinates of neighbour matrices (PCNM, Borcard \& Legendre, 2002; Dray et al., 2006). A similar approach has been recently followed by Tolonen et al. (2017), who studied a littoral macroinvertebrate community in a single aquatic system (the Kitkajärvi lake system, Finland). The PCNM method produces orthogonal spatial variables from a broad to a fine scale to take into account the spatial patterns among replicates. The procedure proposed by Borcard et al. (2011) was followed to construct these spatial variables. A forward stepwise selection procedure was performed to detect the significant PCNM variables and coordinates ( $\mathrm{x}$-axis and $\mathrm{y}$-axis) for community composition, taxa richness and abundance.

For the second approach, log-transformed taxa richness and abundance were modelled by semivariograms, a geostatistical tool that specifically targets to measure the spatial autocorrelation of the measured variables. A semivariogram is a graph in which semi-variance is plotted on the $\mathrm{y}$-axis against the distance classes among sites on the x-axis (Legendre \& Legendre, 1998).

All the analyses and graphs were performed with the base, packfor (Dray et al., 2013), geoR (Ribeiro \& Diggle, 2015), akima (Akima \& Gebhardt, 2015), fields (Nychka et al., 2015), plot3D (Soetaert, 2016) and vegan packages (Oksanen et al., 2016) of the statistical software R (R Core Team, 2016).

\section{RESULTS}

Overall, 5493 organisms belonging to 25 taxa were collected and identified. The most abundant taxon was Chironomidae with 3726 individuals (nearly $68 \%$ of total abundance), followed by Baetis with 893 individuals (16\%) and Naididae with 493 individuals $(9 \%)$. The abundance and detection frequencies of the collected families and genera are reported in Table 1. Most taxa (nearly $70 \%$ ) were observed with detection frequencies below $20 \%$, and 10 of the 25 can be considered low abundance taxa (e.g., Guareschi et al., 2017). The mean depth for each transect ranged from $26 \pm 13$ to $29 \pm 14 \mathrm{~cm}$, while the maxi- 
Table 1. List of taxa found in the Baganza stream, with total abundance, percentage abundance and frequency (expressed as a percentage of samples with the presence of those taxa). The most abundant taxa are marked in bold. Listado de los taxones obtenidos en el tramo estudiado del río Baganza, con datos de abundancia total, porcentaje de abundancia y frecuencia (expresada como porcentaje de muestras con la presencia del taxón). Los taxones más abundantes aparecen en negrita.

\begin{tabular}{|c|c|c|c|c|}
\hline \multirow{2}{*}{ Order } & \multirow{2}{*}{ Taxa } & \multirow{2}{*}{$\frac{\text { Abundance }}{\text { (total) }}$} & \multirow{2}{*}{$\frac{\text { Abundance }}{(\%)}$} & \multirow{2}{*}{$\frac{\text { Frequency }}{(\%)}$} \\
\hline & & & & \\
\hline Anthoathecatae & Hydra & 5 & $0.09 \%$ & $10 \%$ \\
\hline \multirow{2}{*}{ Coleptera } & Dytiscidae & 3 & $0.05 \%$ & $4 \%$ \\
\hline & Elmidae & 1 & $0.02 \%$ & $2 \%$ \\
\hline \multirow{6}{*}{ Diptera } & Ceratopogonidae & 4 & $0.07 \%$ & $4 \%$ \\
\hline & Chironomidae & 3726 & $67.83 \%$ & $100 \%$ \\
\hline & Empididae & 13 & $0.24 \%$ & $22 \%$ \\
\hline & Limoniidae & 1 & $0.02 \%$ & $2 \%$ \\
\hline & Simuliidae & 24 & $0.44 \%$ & $38 \%$ \\
\hline & Tipulidae & 1 & $0.02 \%$ & $2 \%$ \\
\hline \multirow[t]{6}{*}{ Ephemeroptera } & Baetis & 893 & $16.26 \%$ & $100 \%$ \\
\hline & Caenis & 9 & $0.16 \%$ & $18 \%$ \\
\hline & Ecdyonurus & 11 & $0.20 \%$ & $14 \%$ \\
\hline & Electrogena & 12 & $0.22 \%$ & $20 \%$ \\
\hline & Ephemerella & 153 & $2.79 \%$ & $84 \%$ \\
\hline & Rhitrogena & 52 & $0.95 \%$ & $46 \%$ \\
\hline \multirow[t]{2}{*}{ Gastropoda } & Bithynia & 1 & $0.02 \%$ & $2 \%$ \\
\hline & Valvata & 1 & $0.02 \%$ & $2 \%$ \\
\hline \multirow[t]{2}{*}{ Oligochaeta } & Lumbricidae & 3 & $0.05 \%$ & $6 \%$ \\
\hline & Naididae & 493 & $8.98 \%$ & $72 \%$ \\
\hline Plecoptera & Leuctra & 6 & $0.11 \%$ & $12 \%$ \\
\hline Prostigmata & Hydrachnidae & 3 & $0.05 \%$ & $6 \%$ \\
\hline \multirow[t]{3}{*}{ Trichoptera } & Beraeidae & 2 & $0.04 \%$ & $4 \%$ \\
\hline & Leptoceridae & 1 & $0.02 \%$ & $2 \%$ \\
\hline & Hydropsychidae & 7 & $0.13 \%$ & $14 \%$ \\
\hline
\end{tabular}

mum depth was $45 \mathrm{~cm}$ and the minimum depth was $5 \mathrm{~cm}$. The complete depth profile is shown in figure $2 \mathrm{a}$. The spatial patterns of richness and abundance are reported in figure $2 b$ and figure $2 c$, respectively, according to the sampling grid, and they overlapped the depth profile. Higher abundance values were detected near the shoreline (at a depth of 10-20 cm), especially for the left bank, which is characterised by gentle slope. Converse$1 \mathrm{y}$, this pattern was less clear for taxa richness, for which the differentiation between the shoreline and the centre of the stream was smaller.

Community ordination output is reported in figure 3 . The points with different depths are clustered in two different areas of the nMDS plot. This segregation seemed related to depth
$\left(\mathrm{R}^{2}=0.63\right)$ and the $\mathrm{x}$-axis (which represent the transversal position inside the riverbed, $\mathrm{R}^{2}=0.36$ ), while the y-axis showed no relationships.

The variance partitioning results of the whole macroinvertebrate community are reported in figure 4 . The considered variables explained 64 $\%$ of total variance, with the joined contribution of the whole set of explanatory variables accounting for $28 \%$ of total variance, followed by the PCNM variables (19\%), and by PCNM and depth joined $(17 \%)$.

The variance partitioning results for taxa richness and abundance are reported in figure 5. After forward selection, only the $\mathrm{x}$ coordinate, depth and a set of PCNM variables were retained. For taxa richness, the explanatory variables 

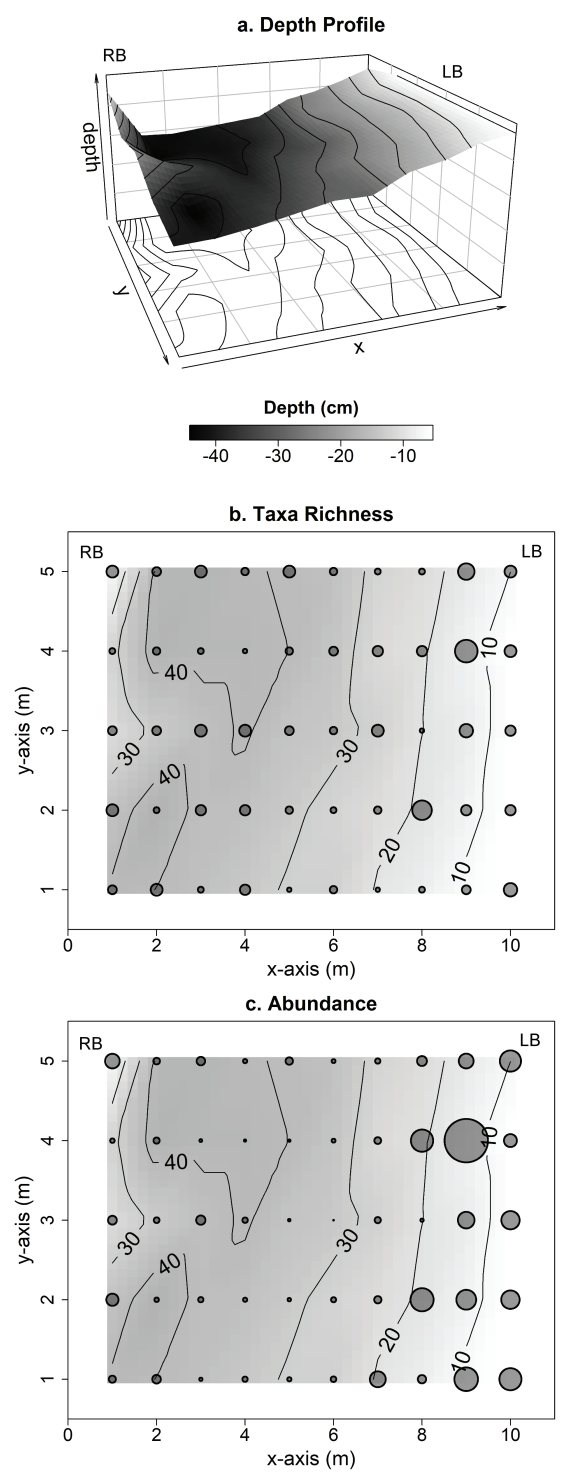

Figure 2. Depth profile $(\mathrm{cm})$ of the sampling reach in the Baganza stream (a). Spatial distributions of Taxa Richness (b) and Abundance of organisms (c), represented by spatially located grey circles overlapping the depth profile expressed in $\mathrm{cm}$. The size of the circles is proportional to the metrics values (taxa richness range 3-15; abundance range 11-479 individuals). $\mathrm{RB}=$ Right riverbank; $\mathrm{LB}=$ Left riverbank. The $\mathrm{x}$ and $\mathrm{y}$ values represent the coordinates of the sampling points inside the grid, with transect on the $y$-axis and the 10 points of each transect on the x-axis. Perfil de profundidad (en $\mathrm{cm}$ ) del tramo estudiado (a). Distribución espacial de la riqueza (b) y abundancia (c) de organismos expresada con puntos grises solapados al perfil de profundidad. El tamaño de los puntos es proporcional a los valores de las métricas (rango riqueza: 5-15; rango abundancia: 11-479 individuos). $R B=$ Orilla derecha; $L B=$ Orilla izquierda. Los valores de los ejes representan las coordenadas espaciales de cada punto dentro de las cuadriculas espaciales (transectos en el eje y, 10 puntos de muestreos en el eje $x$ ).

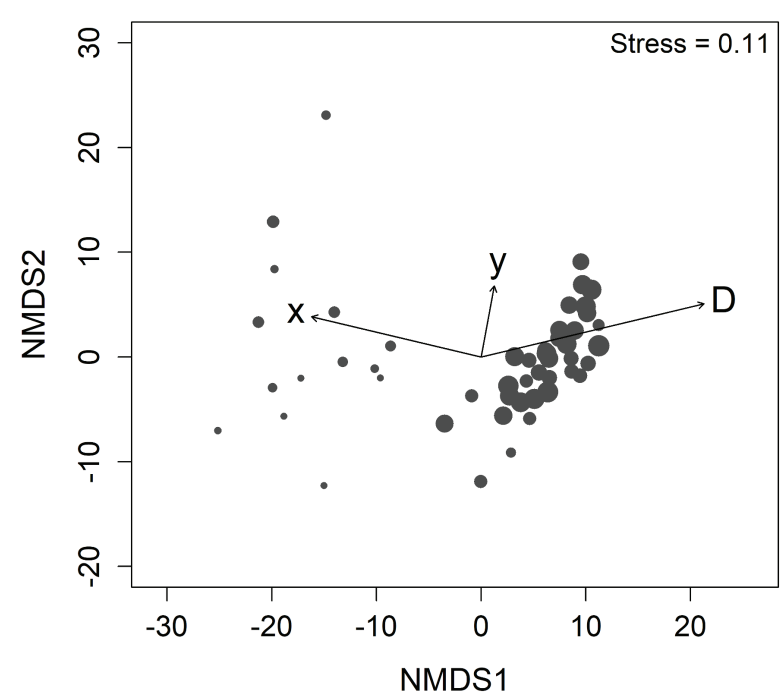

Figure 3. nMDS ordination output. Diameter of dots is proportional to the depth value. Ordination stress $=0.11$. The vectors representing depth and spatial coordinates also overlapped ordination. Resultados de la ordenación nMDS. El diámetro de los puntos es proporcional a la profundidad (valor de estress $=0,11$ ). Los vectores representantes de la profundidad y las coordenadas espaciales están sobreescritos a la ordenación obtenida.

accounted for $24 \%$ of variance, with PCNM explaining $20 \%$. The explanatory variables accounted for $71 \%$ of variance for abundance, with greater contributions made by depth and the PCNM variables joined (26\%), the PCNM variables $(24 \%)$, and all the explanatory variables joined $(22 \%)$.

The semivariograms of the log-transformed taxa richness and abundance are reported in figure 6 (Fig. 6a and Fig. 6b, respectively). Taxa richness lacked a spatial structure, while abundance showed clear spatial autocorrelation with replicates located within a distance of $4.45 \mathrm{~m}$ that correlated with one another. Such autocorrelation (Fig. 6b) disappeared when a semivariogram was applied to the residual values of the regression between abundance and depth (result not shown). This is a common procedure in geostatistic modelling to check the presence of further spatial autocorrelation.

\section{DISCUSSION}

Our study is one of the first that attempts to highlight the importance of small scale spatial 


\section{Community Composition}

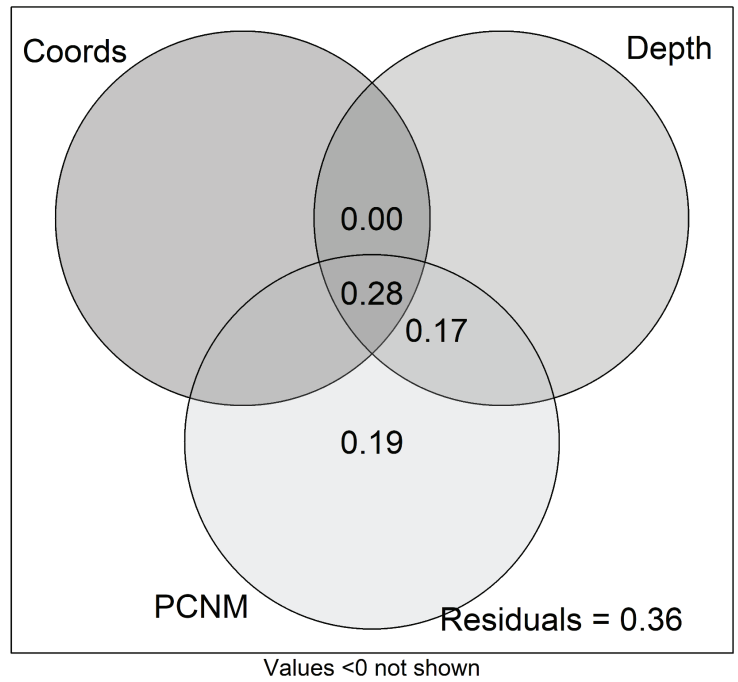

Figure 4. The variance partitioning results for community composition among the components of spatial coordinates, depth and the significant PCNM variables. Residual values are also displayed. Resultados del análisis de la varianza para la composición de la comunidad entre las componentes de coordenadas espaciales, profundidad y las variables significativas del PCNM. También se expresan los valores de los residuos.

location in an aquatic community of an intermittent stream. Our results highlight a spatially structured macroinvertebrate community, where abundance is the variable that most depends on the position inside the riverbed.

According to our results, space plays a double role in the studied stream: it enters models as transversal variation of depth (see the discussion below), but is also a macroinvertebrate community descriptor as a pure spatial fraction. However, how can this double role of space be translated into ecological terms?

The first spatial trend highlighted in our results corresponds to the transversal variation under environmental conditions. Conversely to taxa richness, abundance exhibited a clear trend that was transversally oriented to the watercourse (following the $\mathrm{x}$-axis direction), reflected by both the semivariogram and variance partitioning methods. The community composition results resembled those of abundance, as shown by both nMDS ordination and variance partitioning. Our results clearly show that for the studied Baganza stream reach, depth is spatially structured along the $\mathrm{x}$-axis (see Fig. 2a). In fact, depth proves to be a good predictor of macroinvertebrates abundance, which is not true for taxa richness. A negative relationship of water depth with abundance has already been found in other watercourses (e.g., Collier et al., 1998; Brooks et al., 2005), while opposite results have been reported by Fenoglio et al. (2004) in tropical systems. Lack of a relationship between taxa richness and depth can be attributed to the small gradient measured in the Baganza stream. Relative low depth and small gradients seem quite common in intermittent systems located in lowland and floodout zones, where surface water infiltration into the streambed is related to bed porosity and water table depth (Datry et al., 2017). The negative relationship between abundance and depth can be linked to better food availability near banks (Bournaud et al., 1998; Ferreiro et al., 2011), high water velocity in the riverbed centre that may dislodge organisms (Rempel et al., 2000) or to an interaction of these factors. The macroinvertebrate community in the studied reach was composed mainly of collector gatherers and grazers, such as Chironomidae (chiefly Orthocladiinae and Chironominae), Baetis and Naididae that commonly feed on fine particulate organic matter, or on algae and associated material. Furthermore, the behaviour of some aquatic insects which, during emergence periods go towards shallow water, can also explain this pattern (e.g., Sagnes et al., 2008). These results suggest that while different taxa can choose to occupy almost any position inside the riverbed, their abundance is strictly dependent on depth, and generally dependent on the system's spatial structure. Therefore, on a fine scale, habitat filtering seems to act predominantly on organism abundance.

The second spatial trend, represented by the pure PCNM fraction, depicts a spatial structure that is uncovered by coordinates and depth. In the variance partitioning results (Figs. 4 and 5), consistent portions of variation (for all the examined dependent variables) are ascribable to the PCNM variables alone. They represent the main fraction for taxa richness (Fig. 5a), as well as important fractions for abundance (Fig. 5b) and community composition (Fig. 4). Such fractions can result from biotic interactions, like competi- 
a. Taxa Richness

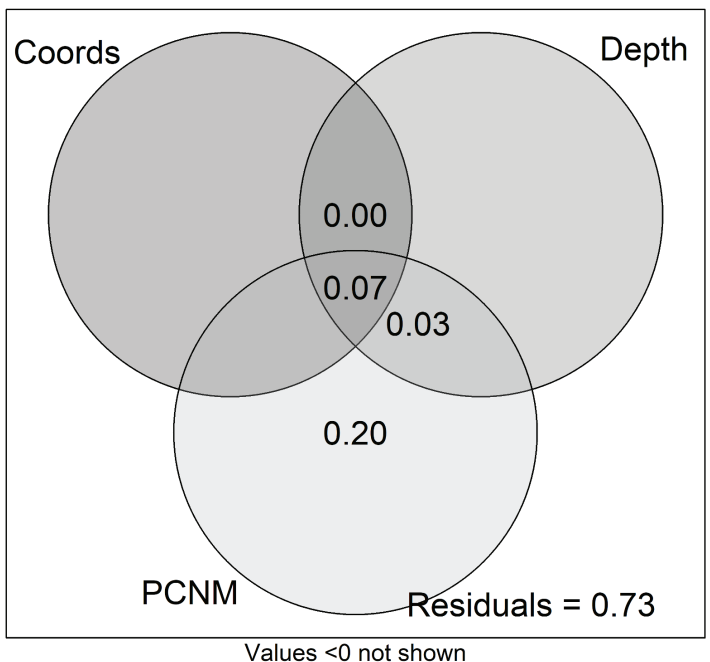

b. Abundance

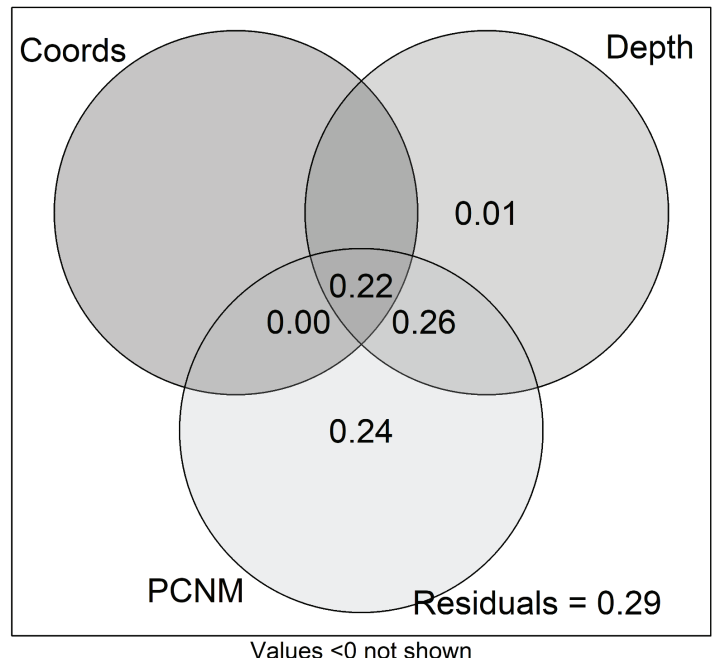

Figure 5. The variance partitioning results for log-transformed Taxa Richness (a) and Abundance (b) among the components of spatial coordinates, depth and the significant PCNM variables (see details in Material and Methods). Residual values are also displayed. Resultados del análisis de la varianza por los valores trasformados de riqueza (a) y abundancia (b) entre las componentes de coordenadas espaciales, profundidad y variables significativas del PCNM (detalles en la Metodología). También se expresan los valores de los residuos.

a. Semivariogram of Taxa Richness

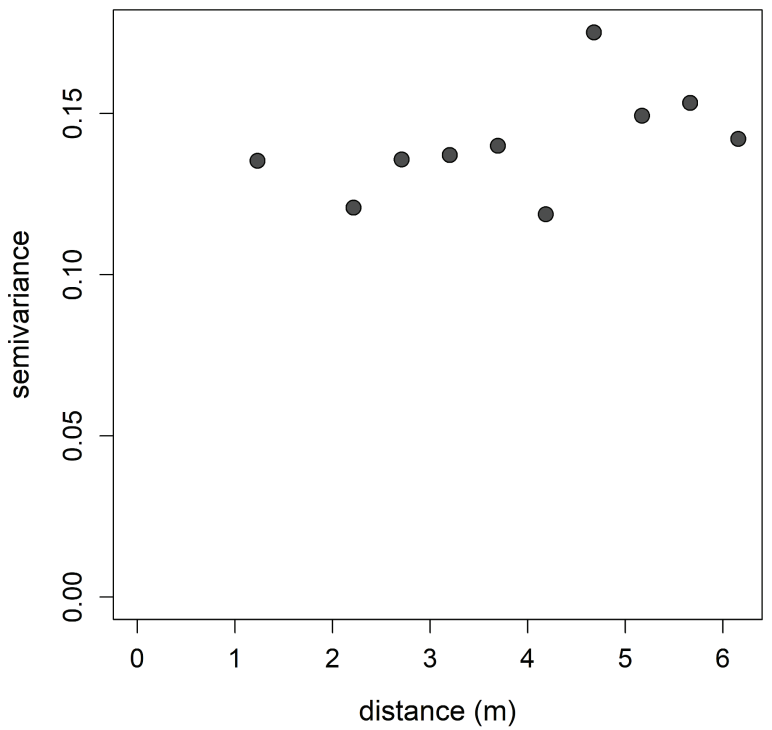

b. Semivariogram of Abundance

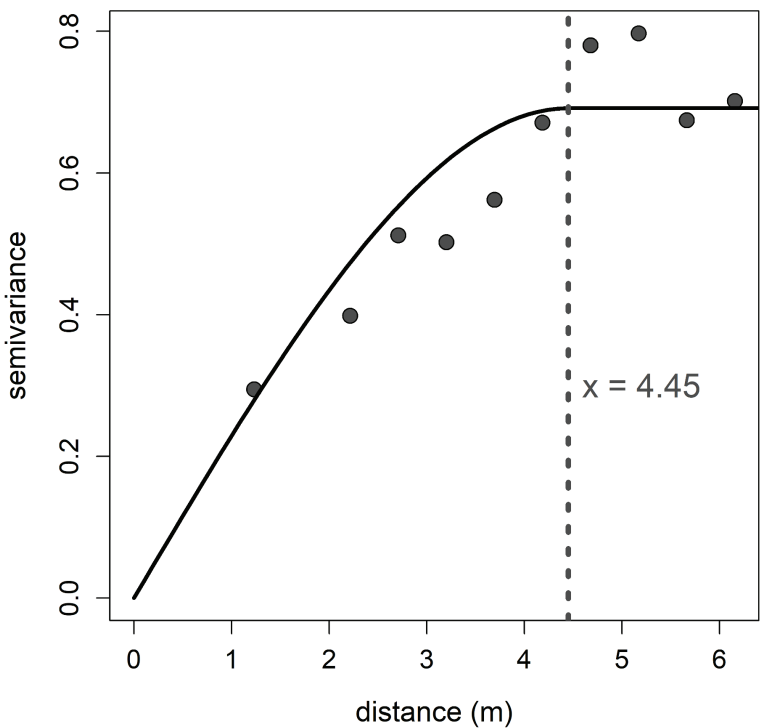

Figure 6. Semivariograms of log-transformed Taxa Richness (a) and Abundance (b). The trend for abundance is marked by the black line. The dotted line stresses the $4.45 \mathrm{~m}$ value (see the main text). Semivariogramas de los valores, después de la transformación logarítmica, de Riqueza (a) y Abundancia (b). En el caso de la Abundancia la tendencia está marcada con la línea de color negro. La línea de punto destaca el valor de 4,45 m (ver texto principal). 
tion and predation, favoured by proximity and drive the small scale distribution of aquatic invertebrates. Nevertheless, this pure spatial fraction can also encompass unmeasured variables.

When we look at the taxonomic list (Table 1), most detected taxa present low detection frequencies and/or low abundance (no. of individuals). Similar findings in abundance and the most common taxa terms have been obtained from invertebrate seedbank composition in British temporary systems (Stubbington et al., 2016).

Small scale variations, low detection frequencies and low abundance taxa may be of relevant importance when considering that the confidence and precision of a biological index can be closely linked to the small scale patchiness of aquatic taxa distribution (Laini et al., 2014; Guareschi et al., 2017). Biomonitoring in these lotic ecosystems represents an open research challenge for bioassessment science (e.g., Prat et al., 2014; Cid et al., 2015). In this context, our case study provides useful insights by considering both the small scale variability of aquatic organisms and the importance of habitat filtering and biotic processes, especially in globally widespread ecosystems such as intermittent streams. Supplementary research (e.g., different basins, distinct conditions and with other explanatory variables) is recommended and would be of scientific global interest to validate our results in a larger geographical context and to complement our knowledge of these systems.

In conclusion, we report that spatial variables act as a proxy of the riverbed structure and, therefore, correlate with the environmental considered variable (only depth in our study, but others can exhibit similar features), and also as a marker of potential biotic interactions. Therefore, including spatial variables on the small scale in community studies can be a useful tool for biomonitoring, river restoration and habitat suitability modelling.

\section{ACKNOWLEDGEMENTS}

The authors are especially grateful to Dr Andrés Mellado-Diaz for his useful comments on an earlier version of the manuscript, and to $\mathrm{S}$. Craighead and H. Warburton (HyA) for the English revision. The authors also wish to thanks anonymous reviewers for inputs and useful suggestions. The contribution of G. Burgazzi is part of her project in the joint doctorate programme in Evolutionary Biology and Ecology (XXX cycle) at the Universities of Ferrara and Parma. G. Burgazzi is granted by the project PRIN-NOACQUA: responses of communities and ecosystem processes in intermittent rivers (Prot. 201572HW8F), A. Laini is partially granted by the University of Parma (Italy).

\section{REFERENCES}

AKIMA, H. \& A. GEBHARDT. 2015. akima: Interpolation of Irregularly and Regularly Spaced Data. R package version 0.5-12. https://CRAN.R-project.org/package=akima

ANDERSON, M. J., K. E. ELLINGSEN \& B. H MCARDLE. 2006. Multivariate dispersion as a measure of beta diversity. Ecology letters, 9: 683-693. DOI: 10.1111/j.1461-0248.2006. 00926.x

ASTORGA, A., R. DEATH, F. DEATH, R. PAAVOLA, M. CHAKRABORTY, \& T. MUOTKA. 2014. Habitat heterogeneity drives the geographical distribution of beta diversity: the case of New Zealand stream invertebrates. Ecology and Evolution, 4: 2693-2702. DOI: 10.1002/ece3.1124

BARNES, J. B., I. P. VAUGHAN \& S. J. ORMEROD. 2013. Reappraising the effects of habitat structure on river macroinvertebrates. Freshwater Biology, 58:2154-2167. DOI: $10.1111 /$ fwb.12198

BO, T., S. FENOGLIO, G. MALACARNE, M. PESSINO \& F. SGARIBOLDI. 2007. Effects of clogging on stream macroinvertebrates: an experimental approach. Limnologica-Ecology and Management of Inland Waters, 37:186-192. DOI: 10.1016/j.limno.2007.01.002 BONADA, N., S. DOLÉDEC \& B. STATZNER. 2012. Spatial autocorrelation patterns of stream invertebrates: exogenous and endogenous factors. Journal of Biogeography, 39:56-68. DOI: 10.1111/j.1365-2699.2011. 02562.x

BORCARD, D. \& P. LEGENDRE. 2002. All-scale spatial analysis of ecological data by means of principal coordinates of neighbour 
matrices. Ecological Modelling, 153:51-68. DOI: 10.1016/S0304-3800(01)00501-4

BORCARD, D., F. GILLET \& P. LEGENDRE. 2011. Numerical ecology with R. Springer Science \& Business Media. New York.

BOURNAUD, M., H. TACHET, A. BERLY \& B. CELLOT. 1998. Importance of microhabitat characteristics in the macrobenthos microdistribution of a large river reach. Annales de Limnologie-International Journal of Limnology, 34:83-98. DOI: 10.1051/limn/1998009

BOYERO, L. \& R. C. BAILEY. 2001. Organization of macroinvertebrate communities at a hierarchy of spatial scales in a tropical stream. Hydrobiologia, 464:219-225. DOI: 10.1023/A:1013922307096

BOYERO, L. 2003. Multiscale patterns of spatial variation in stream macroinvertebrate communities. Ecological Research, 18:365-379. DOI: 10.1046/j.1440-1703.2003.00562.x

BROOKS, A. J., T. I. M. HAEUSLER, I. REINFELDS \& S. WILLIAMS. 2005. Hydraulic microhabitats and the distribution of macroinvertebrate assemblages in riffles. Freshwater Biology, 50:331-344. DOI: 10.1111/ j.1365-2427.2004.01322.x

BRUNO, D., O. BELMAR, D. SÁNCHEZFERNÁNDEZ, S. GUARESCHI, A. MILLÁN \& J. VELASCO. 2014. Responses of Mediterranean aquatic and riparian communities to human pressures at different spatial scales. Ecological Indicators, 45:456-464. DOI: $10.1016 /$ j.ecolind.2014.04.051

BUFFAGNI, A. \& S. ERBA. 2007. Macroinvertebrati acquatici e Direttiva 2000/60/EC (WFD)-Parte A. Metodo di campionamento per $i$ fiumi guadabili. IRSA-CNR Notiziario dei metodi analitici.

CID, N., I. VERKAIK, E. M. GARCÍA-ROGER, M. RIERADEVALL, N. BONADA, M. M. SÁNCHEZ-MONTOYA, R. GOMEZ, M. L. SUAREZ, M. R. VIDAL-ABARCA, D. DEMARTINI, A. BUFFAGNI, S. ERBA, I. KARAOUZAS, N. SKOULIKIDIS \& N. PRAT. 2016. A biological tool to assess flow connectivity in reference temporary streams from the Mediterranean Basin. Science of the Total Environment, 540:178-190. DOI: 10.1016/j.scitotenv.2015.06.086
COLLIER, K. J., R. J. ILCOCK \& A. S. MEREDITH. 1998. Influence of substrate type and physico-chemical conditions on macroinvertebrate faunas and biotic indices of some lowland Waikato, New Zealand, streams. New Zealand journal of marine and freshwater research, 32:1-19. DOI: 10.1080/00288330. 1998.9516802

DATRY, T., S. T. LARNED \& K. TOCKNER. 2014. Intermittent rivers: a challenge for freshwater ecology. BioScience, 64:229-235. DOI: $10.1093 /$ biosci/bit027

DATRY, T., N. BONADA \& A. J. BOULTON. 2017. Intermittent rivers and ephemeral streams: ecology and management. Academic Press. London.

DIGGINS, T. P. \& A. M. NEWMAN. 2009. Environmental and spatial influences on benthic community composition in wooded headwater streams in Zoar Valley, New York, USA. Hydrobiologia, 630:313-326. DOI: 10.1007/s10750-009-9824-7

DOWNES, B. J., J. S. HINDELL \& N. R. BOND. 2000. What's in a site? Variation in lotic macroinvertebrate density and diversity in a spatially replicated experiment. Austral Ecology, 25:128-139. DOI: 10.1046/j.1442-9993. 2000.01019.x

DRAY, S., P. LEGENDRE \& P. R. PERES-NETO. 2006. Spatial modelling: a comprehensive framework for principal coordinate analysis of neighbour matrices (PCNM). Ecological Modelling, 196:483-493. DOI: 10.1016/j.ecolmodel.2006.02.015

DRAY, S., P. LEGENDRE \& G. BLANCHET. 2013. packfor: Forward Selection with permutation (Canoco p.46). $\mathrm{R}$ package version 0.0-8/r109. https://R-Forge.R-project. org/projects/sedar/

FENOGLIO, S., T. BO \& M. CUCCO. 2004. Small-scale macroinvertebrate distribution in a riffle of a neotropical rainforest stream (Rio Bartola, Nicaragua). Caribbean Journal of Science, 40:253-256

FERREIRO, N., C. FEIJOÓ, A. GIORGI \& L. LEGGIERI. 2011. Effects of macrophyte heterogeneity and food availability on structural parameters of the macroinvertebrate community in a Pampean stream. Hydrobio- 
logia, 664:199-211. DOI: 10.1007/s10750010-0599-7

GAYRAUD, S. \& M. PHILIPPE. 2001. Does subsurface interstitial space influence general features and morphological traits of the benthic macroinvertebrate community in streams?. Archiv für Hydrobiologie, 151:667-686. DOI: 10.1127/archiv-hydrobiol/ $151 / 2001 / 667$

GRÖNROOS, M., J. HEINO, T. SIQUEIRA, V. L. LANDEIRO, J. KOTANEN \& L. M. BINI. 2013. Metacommunity structuring in stream networks: roles of dispersal mode, distance type, and regional environmental context. Ecology and Evolution, 3:4473-4487. DOI: 10.1002/ece3.834

GUARESCHI, S., A. LAINI \& M. M. SÁNCHEZ-MONTOYA. 2017. How do low-abundance taxa affect river biomonitoring? Exploring the response of different macroinvertebrate-based indices. Journal of Limnology, 76.s1. DOI: 10.4081/jlimnol. 2016.1516

GUTIÉRREZ-CÁNOVAS, C., D. SÁNCHEZFERNÁNDEZ, J. VELASCO, A. MILLÁN \& N. BONADA. 2015. Similarity in the difference: changes in community functional features along natural and anthropogenic stress gradients. Ecology, 96:2458-2466. DOI: $10.1890 / 14-1447.1$

HEINO, J., P. LOUHI \& T. MUOTKA. 2004. Identifying the scales of variability in stream macroinvertebrate abundance, functional composition and assemblage structure. Freshwater Biology, 49:1230-1239. DOI: 10.1111/ j.1365-2427.2004.01259.x

LAINI, A., A. VORTI, R. BOLPAGNI \& P. VIAROLI. 2014. Small-scale variability of benthic macroinvertebrates distribution and its effects on biological monitoring. Annales de Limnologie-International Journal of Limnology, 50:211-216. DOI: 10.1051/limn/ 20140001

LAINI, A., R. BOLPAGNI, T. CANCELLARIO, S. GUARESCHI, E. RACCHETTI \& P. VIAROLI 2018. Testing the response of macroinvertebrate communities and biomonitoring indices under multiple stressors in a lowland regulated river. Ecological Indicators,
90:47-53. DOI: 10.1016/j.ecolind.2018.02.051 LAMOUROUX, N., S. DOLÉDEC \& S. GAYRAUD. 2004. Biological traits of stream macroinvertebrate communities: effects of microhabitat, reach, and basin filters. Journal of the North American Benthological Society, 23:449-466. DOI: 10.1899/0887-3593(2004) $023<0449$ : $\mathrm{BTOSMC}>2.0 . \mathrm{CO} ; 2$

LEGENDRE, P. \& L. LEGENDRE. 1998. Numerical Ecology (2nd edn). Elsevier Scientific. Amsterdam.

MARTÍNEZ, A., A. BASAGUREN, A. LARRAÑAGA, J. MOLINERO, J. PÉREZ, M. SAGARDUY \& J. POZO. 2016. Differences in water depth determine leaf-litter decomposition in streams: implications on impact assessment reliability. Knowledge and Management of Aquatic Ecosystems, 417:23. DOI: $10.1051 / \mathrm{kmae} / 2016010$

MYKRÄ, H., J. HEINO \& T. MUOTKA. 2007. Scale-related patterns in the spatial and environmental components of stream macroinvertebrate assemblage variation. Global Ecology and Biogeography, 16:149-159. DOI: 10.1111/j.1466-8238.2006.00272.x

NYCHKA, D., R. FURRER, J. PAIGE \& S. SAIN. 2016. fields: Tools for Spatial Data. R package version 8.3-6. https://CRAN.R-project. org $/$ package $=$ fields

OKSANEN, J., F. G. BLANCHET, R. KINDT, P. LEGENDRE, P. R. MINCHIN, R. B. O'HARA, G. L. SIMPSON, P. SOLYMOS, M. H. H. STEVENS \& H. WAGNER. 2016. vegan: Community Ecology Package. R package version 2.3-5. https://CRAN.R-project. org $/$ package $=$ vegan

PARSONS, M., M. C. THOMS \& R. H. NORRIS. 2003. Scales of macroinvertebrate distribution in relation to the hierarchical organization of river systems. Journal of the North American Benthological Society, 22:105-122. DOI: $10.2307 / 1467981$

PERES-NETO, P. R., P. LEGENDRE, S. DRAY $\&$ D. BORCARD. 2006. Variation partitioning of species data matrices: estimation and comparison of fractions. Ecology, 87: 2614-2625. DOI: 10.1890/0012-9658(2006)87 [2614:VPOSDM]2.0.CO;2

PRAT, N., F. GALLART, D. VON SCHILLER, 
S. POLESELLO, E. M. GARCÍA-ROGER, J. LATRON, M. RIERADEVALL, P. LLORENS, G. G. BARBERÁ, D. BRITO, A. M. DE GIROLAMO, D. DIETER, A. LO PORTO, A. BUFFAGNI, S. ERBA, N. P. NIKOLAIDIS, E. P. QUERNER, M. G. TOURNOUD, O. TZORAKI, N. SKOULIKIDIS, R. GÓMEZ, M. M. SÁNCHEZ-MONTOYA, K. TOCKNER \& J. FROEBRICH. 2014. The Mirage Toolbox: An integrated assessment tool for temporary streams. River research and applications, 30:1318-1334. DOI: 10.1002/rra.2757

$\mathrm{R}$ CORE TEAM 2016. R: A language and environment for statistical computing. $\mathrm{R}$ Foundation for Statistical Computing, Vienna, Austria. https://www.R-project.org

REMPEL, L. L., J. S. RICHARDSON \& M. C. HEALEY. 2000. Macroinvertebrate community structure along gradients of hydraulic and sedimentary conditions in a large gravel-bed river. Freshwater biology, 45:57-73. DOI: 10.1046/j.1365-2427.2000.00617.x

RIBEIRO Jr, P. J. \& P. J. DIGGLE. 2015. geoR: Analysis of Geostatistical Data. R package version 1.7-5.1. https://CRAN.R-project.org/ package $=$ geoR

SAGNES, P., S. MERIGOUX \& N. PERU. 2008. Hydraulic habitat use with respect to body size of aquatic insect larvae: Case of six species from a French Mediterranean type stream. Limnologica-Ecology and Management of Inland Waters, 38:23-33. DOI: 10.1016/j.limno.2007.09.002

SIQUEIRA, T., L. M. BINI, F. O. ROQUE, S. R. MARQUES COUCEIRO, S. TRIVINHOSTRIXINO \& K. COTTENIE. 2012. Common and rare species respond to similar niche processes in macroinvertebrate metacommunities. Ecography, 35:183-192. DOI: 10.1111/j.1600-0587.2011.06875.x
SKOULIKIDIS, N. T., S. SABATER, T. DATRY, M. M. MORAIS, A. BUFFAGNI, G. DÖRFLINGER, S. ZOGARIS, M. M. SÁNCHEZ-MONTOYA, N. BONADA, E. KALOGIANNI, J. ROSADO, L. VARDAKAS, M. A. DE GIROLAMO \& K. TOCKNER. 2017. Non-perennial Mediterranean rivers in Europe: status, pressures, and challenges for research and management. Science of The Total Environment, 577:1-18. DOI: $10.1016 /$ j.scitotenv.2016.10.147

SOETAERT, K. 2016. plot3D: Plotting Multi-Dimensional Data. R package version 1.1. https://CRAN.R-project.org/package=plot3D

STOCH, F., M. KORN, S. TURKI, L. NASELLIFLORES \& F. MARRONE. 2016. The role of spatial environmental factors as determinants of large branchiopod distribution in Tunisian temporary ponds. Hydrobiologia, 782:37-51. DOI: $10.1007 / \mathrm{s} 10750-015-2637-y$

STUBBINGTON, R., J. GUNN, S. LITTLE, T. P. WORRALL \& P. J. WOOD. 2016. Macroinvertebrate seedbank composition in relation to antecedent duration of drying and multiple wet-dry cycles in a temporary stream. Freshwater Biology, 61:1293-1307. DOI: 10.1111/ fwb. 12770

TACHET, H., P. RICHOUX, M. BOURNAUD \& P. USSEGLIO-POLATERA. 2010. Invertébrés d'eau donce: systématique, biologie, écologie. CNRS. Paris.

TOCKNER, K., U. UEHLINGER, C. T. ROBINSON, D. TONOLLA, R. SIBER \& F. D. PETER. 2009. Rivers of Europe. Academic Press. London.

TOLONEN, K. T., A. VILMI, S. M. KARJALAINEN, S. HELLSTEN, T. SUTELA \& J. HEINO. 2017. Ignoring spatial effects results in inadequate models for variation in littoral macroinvertebrate diversity. Oikos, 126:852-862. DOI: 10.1111/oik.03587 